УДК: 808.41

DOI: 10.33184/YVDK-2021-04-30.22

С.А. Питина (проф. ЧелГУ, г. Челябинск), А.В. Таскаева (доц. ЮУрГИИ им. П.И. Чайковского, 2.Челябинск)

\title{
ОСОБЕННОСТИ ГЕРОИЗАЦИИ И ДЕГЕРОИЗАЦИИ В РЕГИОНАЛЬНОМ ЯЗЫКОВОМ ЛАНДШАФТЕ
}

B cтатье рассматриваются особенности двух противоположных, но идеологически маркированных прочессов: героизачии и дегероизачии. В результате анализа эмпирического материала авторы приходят к выводу о том, что прочесс героизачии в топонимах Челябинской области репрезентирован посвященными названиями историческим событиям и именам. Дегероизация репрезентирована народными топонимами и переименованиями.

Ключевые слова: героизация, дегероизация, коммеморатив, топоним, народный топоним.

The article views peculiarities of glorification and deglorification, the two opposite but ideologically connected processes. The analysis of empirical material has shown that glorification is represented in Chelyabinsk region place names by commemoration of historical events and famous people while deglorification is realized in folk place names and renamings.

Key Words: glorification, deglorification, commemorative name, place name, folk place name.

Настоящая работа выполнена в рамках относительно нового интегрального направления лингвистических исследований - героической лингвистики, «в центре которого находится лингвокультурный концепт ГЕРОИЗМ и его ядерная репрезентация в виде лингвокультурного типажа ГЕРОЙ» [Таскаева, Питина 2020: 6]. В процессе героизации формируется героическая парадигма, в которой вербализуется как концепт ГЕРОИЗМ, так и лингвокультурный типаж ГЕРОЙ. 
Репрезентация процесса героизации в языковом ландшафте страны в целом и региона в частности является универсальным явлением. Характерными особенностями героизации являются:

1. Идеологизированность процесса;

2. Стереотипность и повторяемость героических номинаций;

3. Связь с историческими событиями;

4. Открытый характер героической парадигмы, еe обновляемость;

5. Узнаваемость имен героев и признание героями большинством населения;

6. Дегероизация и, как следствие, переименования в результате смены идеологии.

Героические номинации в региональном языковом ландшафте Челябинской области в полной мере отражают указанные универсальные характеристики героизации, с одной стороны, и уникальные особенности данного процесса, с другой. Рассмотрим коммеморативные топонимы Челябинской области как одну из составляющих героической парадигмы. Примеры коммеморативных топонимов взяты из [Дегтярев 1960; Макеев, электронный ресурс; Матвеев 2001; Пятков 2004; Шувалов 1989].

Коммеморативные топонимы региона представлены:

1. Универсальными коммеморативами, появившимися в период освоения и заселения региона. Топонимы Атамановское, Императорское, Княженское, Наследницкое. Они являются обобщающими названиями и подверглись переименованию или дегероизации в советский период.

2. Универсальными коммеморативами, возникшими после Октябрьской революции или в период существования Советского Союза, не изменившими своих названий после перестройки, хотя и утратившими «героические» коннотации. К таким названиям отнесем номинации населенных пунктов Слава, Пионерский, Целинный и др. В советский период на карте региона появились многочисленные коммеморативные топонимы, отражающие официальную идеологию и историю: Большевик, Красноармейский, Краснооктябрьский, Красносельское, Красная Заря, Красный Октябрь, Красный Партизан, Марксист, Октябрьское, Победа, Спутник и др. «Неологизмом, 
характерным для 1920-30-х гг., является топоним Радиомайка (в честь Дня радио - 7 мая)» [URL: http://chelportal.ru/enc/toponimika]. По другой версии название села связано c установленным на сопке радиомаяком. Село было переименовано в честь радиофикации деревни, утратив древнее название Каменский. Необычный композит с прозрачной этимологией для сельских жителей 20-30 гг. ХХ в. Радиомайка и неоднозначно воспринимаемый в настоящее время является оригинальным примером словосложения и суффиксации.

3. Коммеморативами-историзмами, в которых отражены исторические события, победы русской армии в войнах. Около 40 топонимов на территории казачьих поселений названы в честь Отечественной войны 1812 г., заграничных походов русской армии 1813-1814 гг,, русско-турецких войн: Арсинский, Березинский, Бородиновка, Бреды, Кацбахский, Краснинский, Лейпџиг, Париж, Тарутино, Фершампенуаз. Топонимы Балканы (переименованный в 1933г. Балканский), Браиловский, Варна, Измайловский, Карсы, Карский, Наваринка, Рымникский, Чесма названы в честь сражений в русско-турецких войнах XVIII-XIX вв. Итальянский поход А. В. Суворова 1799 г. отражен в коммеморативном топониме Новинка - современном переименовании топонима Новинский и названии населенного пункта Требиятский. Топонимы Варшавка и Остроленский являются коммеморативами, в которых репрезентировано участие южноуральских казаков и нагайбаков в подавлении польского восстания 1830-31 гг. Участники подавления восстания в настоящее время воспринимаются скорее как антигерои, однако памятные топонимы Варшавка и Остроленский остались на карте области в русифицированном виде, утратив идеологическую компоненту. Связь с русско-японской войной 1904-1905 гг. прослеживается в топониме Порт-Артур.

Наряду с русификацией иностранного топонима, заключающейся в добавлении русских топонимических суффиксов к названию иностранного топонима: Арсинский, Браиловский, Измайловский, Карский, наблюдается значительное упрощение формы заимствованного в русский язык ойконима: Арсинский (первоначальное название казачьего поселения $A p c u$ Сюр в честь победы над Наполеоном в сражении под Apcu-сюр- 
Обе). В данном примере сохранена только первая часть оригинального топонима.

Следует отметить, что двусложные заимствованные топонимы не трансформируются: Берлин, Париж, Бреды. Трансформация оригинального топонима в результате использования суффиксации характерна и для ряда русских коммеморативов: Бородиновка, Новинка. Под влиянием народной этимологии происходит упрощение сложного для произношения названия: Фершенка (о локальных народных топонимах см. Питина 2014). Жители населенных пунктов с историческими коммеморативными названиями не воспринимают такие названия как героические.

4. Коммеморативами-антропонимами, которые представлены в топонимах Челябинской области несколькими подсистемами онимов. Мы классифицируем такие названия по хронологическому принципу и с точки зрения наличия в них универсальных характеристик и уникальных региональных особенностей.

Универсальные коммеморативы возникли в связи со строительством новой пограничной линии в 1835-1836 гг. и получили названия в честь царей и представителей императорской фамилии: Александровское, Алексеевка, Андреевское, Анненское, Варваринка, Великопетровка, Владимирское, Георгиевское, Еленинка, Натальинское, Николаевское, Павловское и др.

В советский период некоторые населенные пункты с прозрачной этимологией подверглись дегероизации и были переименованы: Царево-Александровский прииск - в Ленинск, село Кулахта - в Ларино.

Советские названия включают в себя имена революционеров, полководцев, государственных и партийных деятелей, включая иностранные имена: Томинский, Чапаевский, Калининский, Кировский, Роза, Тельмана. Коммеморативы советским ученым редко встречаются в языковом ландшафте области: Мичуринский, Тимирязевский. Универсальные коммеморативы встречаются повсеместно. Будучи максимально идеологизированными и обусловленными коммеморативной практикой Советского периода, такие названия не отличаются оригинальностью. 
Уникальные локальные коммеморативы-антропонимы представляют больший интерес для исследования, поскольку в их значениях реализована как идеологическая, так и региональная составляющая, позволяющая проследить важные этапы истории Южного Урала, героизированные в именах создававших ее людей.

1. Посвящения первопоселенцам.

Первыми на территории области появились памятные названия первопоселенцам, записавшимся в городовые казаки крестьянам, которые были набраны основателем Челябинска А. И. Тевкелевым согласно указу 1736 г. На карте области до сих пор сохранились отименные топонимы Баландино (от Баландин), Бутаки (от Бутаков), Бухарино (от Бухарин), Долгая (от Долгий), Исаково (от Исаков), Казанцево (от Казанцев), Костыли (от Костылев), Мальшево (от Малышевых), Першино (от Першин), Полетаево (от Полетаев), в названии пригорода Челябинска и одноименного озера Синеглазово (от Синеглазов), станции и поселка Смолино (от Смолин), Сухомесово (от Сухомесов), Фатеевка (от Фатеев), Федоровка (от Федоров), Чурилово (от Чурилов), Шершни (от Шершнев), и многие другие. Сохранившиеся именные названия бывших казацких заимок стали обозначать более крупные населенные пункты, постепенно утрачивая героические коннотации, хотя в период появления таких названий они тоже просто заменяли цифры. Самые многочисленные фамилии казаков-первопоселенцев дали названия нескольким населенным пунктам и даже озерам: Смолино, Синеглазово.

2.Посвящения казачьим атаманам и губернаторам.

В региональном языковом ландшафте встречаются коммеморативы в честь атаманов Оренбургского казачьего войска и губернаторов края (большая часть южной территории современной Челябинской области входила в состав Оренбургской губернии). Имена атаманов П. О. Агапова (Агаповский), К.Н.Боборыкина (поселок Бабарыкинский с измененной орфографией онима), А. А. Углицкого (поселок Углицкий) и др. отражены в региональной коммеморативной топонимике.

3.Посвящения башкирским старшинам. 
Локальными

антропонимами, отраженными в сохранившихся названиях башкирских сел и деревень. Посвященные названия башкирским старшинам отражают поликультурный языковой ландшафт Челябинской области: Аязгулова, Байгазина, Махмутова и др.

4. Посвящения горнозаводчикам и земледельцам.

В качестве примеров приведем немногочисленные коммеморативы, которых отражены имена горнозаводцев. Вторая часть сложного коммеморатива, являющегося гидронимомантропонимом Катав-Ивановск содержит башкирское название реки, происходящее от этнонима «катай», в то время как вторая часть топонима связана с именами купца и промышленника Ивана Твердышева и его зятя Ивана Мясникова. Аналогичным способом образован коммеморатив Нязепетровск. В названии города объединены башкирский гидроним Нязя и имя основателя завода Петра Осокина. Село Клеопино, основанное в 1753 г. земледельцем Н. Г. Клеопиным, до сих пор носит его имя.

5. Посвящения предводителям восстаний.

Примерами таких посвящений являются Пугачевский, Степана Разина.

Коммеморативы Челябинской области разнообразны по форме и содержанию. Следует отметить, что как универсальные, так и локальные коммеморативы Челябинской области редко подвергались и подвергаются переименованию, хотя со временем они утрачивают идеологическую и героическую составляющие. Дегероизации коммеморативов способствует и народная этимология, в результате которой искажается первоначальная форма коммеморатива.

\section{ЛИТЕРАТУРА}

1. Дегтярев И.В. Из истории заселения местности по среднему течению реки Миасс (начальный период) // Краеведческие записки: сборник. - Челябинск, 1960. Вып.2. - С.13-25.

2. Макеев Г. Топонимы // По тропам Южного Урала: Путеводитель вольного странника [Электронный pecypc].

URL: 
https://www.southural.ru/articles/17568 обращения: 24.02.2021).

3. Матвеев А.К. Топонимия Урала как памятник языка и истории // Известия Уральского государственного университета (Екатеринбург). 2001. № 19. - С. 7-11.

4. Питина С.А. Топонимы и народные топонимы Челябинской области // Вестник Челябинского государственного университета. Филология. Искусствоведение. 2014. Вып. 93. № 26 (355). - С. 92-95.

5. Пятков В.В. Топонимы Южного Урала. Челябинск: Челябинский казак, 2004. - 276 с.

6. Таскаева A.B., Питина С.А. Героическая лингвистика: монография. - Челябинск, 2020 - 179 c.

7. Шувалов Н.И. От Парижа до Берлина по карте Челябинской области: топонимический словарь. 2 е изд., перераб. и доп. - Челябинск : Юж.-Урал. кн. изд-во, 1989. - 158 с. [Электронный ресурс]. URL: http://chel-portal.ru/enc/toponimika (дата обращения: 24.02.2021).

Исследование выполнено при финансовой поддержке РФФИ и Челябинской области в рамках научного проекта № 20-412-740007.

(C) Питина С.А., Таскаева А.В., 2021 г. 